\title{
GENDER BASED STUDENTS' LEARNING AUTONOMY IN ENGLISH FLIPPED CLASSROOM
}

\author{
LENI IRIANTI \\ Universitas Galuh \\ bulen.lenie@gmail.com \\ SYAFRYADIN \\ University of Bengkulu \\ Syafryadin@unib.ac.id \\ ELDA RESI MONETA WIBOWO \\ Universitas Galuh \\ eldaresi98@gmail.com \\ R. BUNGA FEBRIANI \\ Universitas Galuh \\ bunga.febriani@gmail.com
}

DOI: 10.29300/ling.v7i1.3961

Received: January $3^{\text {rd }}, 2021$

Accepted: March $16^{\text {th }}, 2021$

Published: July $14^{\text {th }}, 2021$

\begin{abstract}
This research is aimed at finding out the effectiveness on applying flipped classroom to enhance learning autonomy and how its impact on gender based students' learning autonomy. The researchers was applied convergent parallel mixed methods design. The populations of this study were senior high school in Pangandaran and the researchers selected a particular class. The class which participated is X MIPA 4 which consist of 11 male and 19 female as the experimental group and X MIPA 1 as the control one which consist of 12 male and 18 female. The totals of participants are 60 students. The data collected from pre-post Learning Autonomy Questionnaire (LAQ) and pretest-posttest as quantitative data and interview as qualitative data. The questionnaire was analyzed by using SPSS 16.0 for Windows. The result showed there is a significant difference in students' learning autonomy between students who are taught by means of flipped classroom and those who are not. Moreover, female indicates more autonomy than male in both classes even before or after the treatment. Pretest-posttest indicated although the score of autonomy is increased, it does not have significant impact on their narrative reading comprehension test. On the other hand, based on the interview both female and male students respond positively about applying flipped classroom to enhance their learning autonomy even though there is no huge difference for male. In conclusion, flipped classroom has given a good impact in students' learning autonomy even for female or male students although not give significant impact in students' learning outcomes especially in narrative reading comprehension.
\end{abstract}

Keywords: Flipped classroom, students' learning autonomy, gender identity

\section{INTRODUCTION}

Nowadays, autonomy in the learning process has been one of the important parts in education related to the skills need in the curriculum. Some experts, Santikarn and Wichadee (2018, p. 125) have been mentioned that autonomy is considered a goal of the education in

How to cite this article:Irianti, L., Syafryadin, S., Wibowo, E., \& Febriani, R. (2021). Gender Based Students' Learning Autonomy in English Flipped Classroom. Linguists : Journal Of Linguistics and Language Teaching, 7(1), 52-66. doi:http://dx.doi.org/10.29300/ling.v7i1.3961 
the 21 st century. In line with the goal of the education in the 21 st century and the principles of the lesson plan which contained in Curriculum 2013, flipped classroom can be a perfect choice to be applied. The basic approach in designing lesson plan in classroom practices should be students' center, support independent learning and applying Information and Communication Technology (ICT) because ICT can assist the students and teachers in teaching and learning process (Azwandi, et al. 2019; Anggitasari, et al. 2020; Handayani, et al. 2020; Syafryadin, et al. 2020; Syafryadin \& Syahrial, 2020)

Gender identity theory has been used in applied educational research up to day (Vantieghem et al., 2014, p. 376). In several research articles, it is explained that gender identity can influence learning outcomes, the finding of the research was explained gender identity can affect students' performance (Awan \& Azeem, 2017, p. 369). Its proof that gender identity take place on students' outcome. Most of the researchers study the gender identity research around the concepts of masculinity and femininity of students and the effect to learning outcomes on their attitudes also the motivation. None of them study the gender identity and the relation with students' learning autonomy. Thus, the present study is aimed at how flipped classroom has an impact on students' learning autonomy.

\section{Flipped Classroom}

Flipped Classroom model has been broadly applied to extend teaching practices in numerous subject and level of education, coverage auspicious results for enhancing student learning experiences (Kostaris et al., 2017 p. 261). The from of experiences in a range of perspectives, specifically, cognitive learning outcomes, distribution of different types of learning activities during the face-to-face sessions, levels of motivation during the learning activities, and level of students' engagement during the learning activities.

Basically, the concept of a flipped class is activities which traditionally completed in the class, here is completed at home, and that which is traditionally completed as homework, here is completed in the class (Begarmann \& Sams, 2012, p. 13). Additionally, Maninun \& Kittichartchaowalit as cited in Irianti \& Sulastri (2018, p. 250) flipped classroom is educational process when students attend face-to-face classes they already have some theoretical knowledge and understanding of the matter that will be discussed in the classroom. The point is about teaching and learning process in how the teacher and the students flip the activities between what usually do in the class and what usually do in the home. 


\section{Students' Learning Autonomy}

In the latest curriculum, students are emphasized to be autonomous learner (Martina \& Afriani, 2020). That is the basis why students' learning autonomy has been researching a lot. The essence of learner autonomy is the ability to take charge of one's own learning (Little, 2007, p. 15). According to Benson \& Voller (1997, pp. 1-2) were explained, in language education, autonomy can be defined in at least five different ways: in which learners study in their own pace, self-directed learning, the own ability, the learners can take the responsibility of their own learning and the last the learner can choose the appropriate style with their own learning.

In recent years, students' learning autonomy is one of the focus of the field of study in education as explained, over the last two decades, autonomy and independence have taken on a growing importance in the field of language education (Benson \& Voller, 1997, p. 1). This is supported by Loi (2017, p. 118) in which he claims learner autonomy plays an important position in language education since it can improve learning achievements. In line with what have explained in the background of the study, students' learning autonomy is increasingly being researched and discussed in the world of education to meet the demands of the latest curriculum.

Najeeb (2012, p. 1240) claims that there are three basic pedagogical principles which underlines autonomy in language learning. These are learner involvement (engaging learners to share responsibility for the learning process), learner reflection (helping learners to think critically when they plan, monitor and evaluate their learning) and appropriate use of target language. These basic principles can create and enhance various abilities of students related to themselves, including developing student self-management, building a sense of responsibility towards learning, and can create and develop goal-oriented learning plans, thus the students can be an autonomous learner and can improve learning ability.Thus, the researchers conclude that students' learning autonomy can define as how they can set own learning goals and choose the appropriate learning style and pace to achieve the learning goals.

\section{Gender Identity}

Gender identity is one of the factors studied in its influence with education. Among those are motivations, influence, also attitudes that affect their learning outcomes, and how the gender differences takes place in learning process especially in learning English as Foreign Language. As explained before, Awan and Ameez (2017, p. 353) defined gender 
refers to how an individual sees himself or herself in terms of masculine and feminine tendencies. On the other hand, Bussey (2011, p. 604) asserts gender is referring to socially influenced differences and individual characteristics of the person, whereas others focus on social roles and social structures.

Based on the theories, gender identity is the existence of person as female and male and their characteristics in carrying out their roles in social life. It means gender identity is not only about personal matter, but there is a social aspect. Based on gender role, the person doing an actions and placing theirselves in accordance with their gender identity.

Numerous researcherss conducting studies to seek the impact of gender identity in learning outcomes. As was cited in Chan (2018, p. 65), female students in Hong Kong generally have better academic results in the public examination in English language. Similarly, Becirovic (2017, p. 217) conducted a study the relationship of gender identity with the achievement in learning English as Foreign Language which showed female students has higher achievement than male students. In contrast, he said gender is an important factor influencing motivation and achievement in learning English as a foreign language. Then, Awan and Azeem (2017, p. 369) in their study revealed that girls performed better than boys in curricular and co-curricular activities. On the other hand, even the gender identity is proved can impact learning outcomes, there is no previous study revealed the relation between gender identity and their learning autonomy clearly.

\section{METHOD}

The researchers conducted a convergent parallel mixed methods design. The purpose of applying this sort of research design is to have an exhaustive understanding of the subject investigated. In this case, quantitative data were collected by administering pre and post Learning Autonomy Questionnaire (LAQ) and administering focus group interview as qualitative data collection. The questionnaire was adapted from Zhang and Li (2004) and the questions of interview are following up the statement in the questionnaire adapt from Aderson (2015). This study used true-experimental pretest-posttest design. Pretest-postest completed with students reading comprehension test.

The researchers gave the treatment of flipped classroom in experiment class and applying discovery learning method in control group. The researchers was used cluster random sampling to select a particular class which was participated in this study, that is the tenth grade in one of Senior High School in Pangandaran. The researchers selected two classes as the participant of this research. The class which participated is X MIPA 4 which 

consist of 30 students, 11 male students and 19 female students as the experimental group and X MIPA 1 as the control one which consist of 30 students, 12 male students and 18 female students. The totals of participants are 60 students.

This study used data analysis method, namely statistic descriptive method. The analysis process used in the present study employed SPSS 16.0 for Windows. Qualitative data which collected by using focus group interview was analyzed by using thematic analysis. Thematic analysis is essentially a method for identifying and analyzing patterns in qualitative data (Clarke \& Braun, 2013). Last, according to Creswell (2014, p. 273) the researchers used a side-by-side comparison to gain the final result of this study.

\section{FINDINGS AND DISCUSSIONS}

\section{Findings}

\section{Learning Autonomy Questionnaire Result}

After employing SPSS 16.0 for Windows, based on the questionnaire, the researchers found gender respons which was discussed in the table 1 and 2 :

Table 1 Gender Response of LAQ in Experimental Class

\begin{tabular}{|c|c|c|c|c|c|}
\hline \multirow{2}{*}{ Gender } & \multirow{2}{*}{$\mathrm{N}$} & \multicolumn{2}{|c|}{ Mean } & \multicolumn{2}{c|}{ Std. Deviation } \\
\cline { 3 - 6 } & & Pre LAQ & Post LAQ & Pre LAQ & Post LAQ \\
\hline Male & 11 & 25.18 & 46.90 & 1.991 & 8.665 \\
\hline Female & 19 & 29.74 & 51.47 & 4.736 & 3.322 \\
\hline
\end{tabular}

Table 2 Gender Response of LAQ in Control Class

\begin{tabular}{|c|c|c|c|c|c|}
\hline \multirow{2}{*}{ Gender } & \multirow{2}{*}{$\mathrm{N}$} & \multicolumn{2}{|c|}{ Mean } & \multicolumn{2}{c|}{ Std. Deviation } \\
\cline { 3 - 6 } & & Pre LAQ & Post LAQ & Pre LAQ & Post LAQ \\
\hline Male & 12 & 28.83 & 35.91 & 5.306 & 6.444 \\
\hline Female & 18 & 33.44 & 42.44 & 4.260 & 3.760 \\
\hline
\end{tabular}

On the table 1 and 2 , it could be seen based on the score, female indicates more autonomy than female in both of class even before the treatment or after the treatment. In this present study the researchers was found similar findings in the concept of autonomy that female perfomed better in their autonomy than male. This findings were consistent with previous work conducted by Awan and Azeem (2017, p. 369) they mentioned girls performed better than boys in curricular and co-curricular activities. 
Then, the researchers revealed the descriptive statistic of the questionnaire. Based on the result of questionnaire, experimental class got more positively in their autonomy after the treatment of flipped model than control class with the treatment by using discovery learning. The items number 12 and 14 in post LAQ experimental class is proven that after applying flipped classroom, the students respond positively. Moreover, it could be seen, means of score in experimental class and control class both of female and male have huge different, it showed treatment class performed better in their autonomy. This result is consistent with the findings the study by Santikarn and Wichadee (2018, pp. 103-135) which mentioned that the class which taught by flipped classroom was becoming an autonomous learner. Next step is independent sample t-test was showed in the table 3:

Table 3.T-Test N-Gain of LAQ

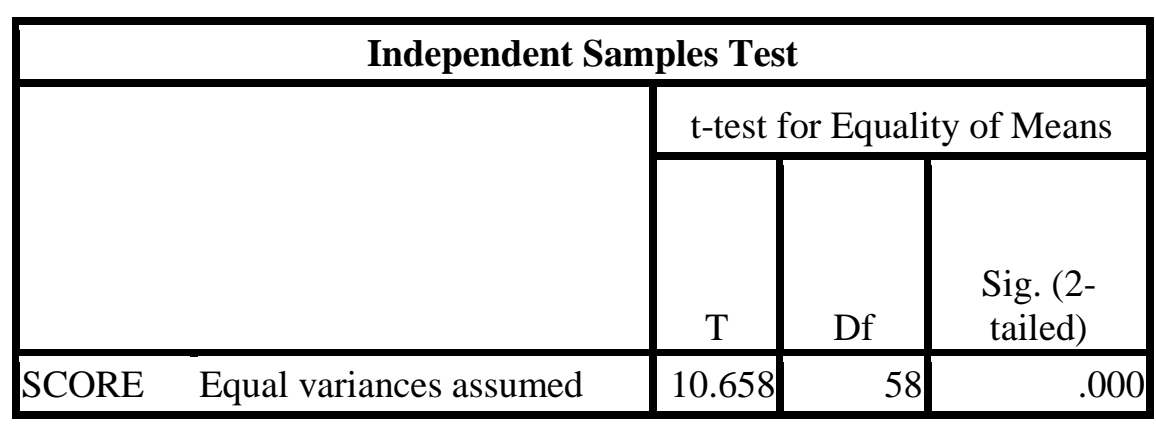

Based on the table 3, the result of $t$ test of $\mathrm{N}$ Gain is shown the value of significant 0.000 which is lower than 0.05 , it can be concluded that $\mathrm{H} 0$ is refused. Its shows that there is a significant difference in students' learning autonomy between students who are taught by means of flipped classroom and those who are not. The result is similar with the findings of the study by Wahaibi and Hashim (2018, p. 99) the learners in the experimental group assessed their autonomy more positively than those in the control group.

\section{Pretest-Posttest Result}

The researchers was took the academic data based on the results of the pretest and posttest as supporting data from the Learning Autonomy Questionnaire (LAQ), whether the test results are in line and support the results of the Learning Autonomy Questionnaire (LAQ) or not. After conducting LAQ and test, the researchers make a comparisons score between LAQ and test experimental class and control class.

In experimental class, each students got higher score in post LAQ than pre LAQ. On the other hand, for the test result there is one students got lower score in their post-test, there are 15 students got higher in their post-test and there are 14 students who got the same score 

in their pre and post test. It could be seen, although the score of autonomy is increased, it does not have significant impact on their narrative reading comprehension test.

In control class, each students got higher score in post LAQ than pre LAQ. On the other hand, for the test result there is one students got lower score in their post-test, there are 7 students got higher in their post-test and there are 22 students who got the same score in their pre and posttest. It could be seen, although the score of autonomy is increased, it does not have significant impact on their narrative reading comprehension test.

Finally, the result of pretest-posttest is indicated although the score of autonomy is increased, it does not have significant impact on their narrative reading comprehension test. It can be concluded the test results are not support the results of the Learning Autonomy Questionnaire (LAQ).

\section{Interview Result}

Interview data collection was administered to answer the first research question: "To what extend does the use flipped classroom in English class impact gender based students' learning autonomy?" The result of analysis in coding the data explained in table 4:

Table 4. Interview Data Analysis - Female

\begin{tabular}{|c|c|c|}
\hline \multicolumn{3}{|c|}{ Interview Data Analysis } \\
\hline Group of Code & Code & Description \\
\hline $\begin{array}{l}\text { Level of Autonomy: } \\
\text { Advanced } \\
\text { Intermediate } \\
\text { Beginning }\end{array}$ & $\begin{array}{l}- \\
- \\
\text { Recognizing one's own needs and } \\
\text { limitation. } \\
\text { Learner reflects learning process, } \\
\text { and thinks about oneself as a } \\
\text { learner. } \\
\text { Learner recognize her limitation } \\
\text { and can chooses suitable learning } \\
\text { materials, methods and strategies. } \\
\text { Managing own's learning } \\
\text { Students have learning process. } \\
\text { - }\end{array}$ & $\begin{array}{l}\text { Based on the codes, even the } \\
\text { female students have autonmy } \\
\text { activities and characteristics, they } \\
\text { still can not optimize those } \\
\text { activities. Then, the researchers } \\
\text { can be concluded that ffemale } \\
\text { students are in beginning level of } \\
\text { autonomy. }\end{array}$ \\
\hline Emerging & & \\
\hline $\begin{array}{l}\text { Is flipped classroom makes you } \\
\text { more autonomous? } \\
\text { Yes }\end{array}$ & $\begin{array}{l}\text { This learning activities are more } \\
\text { interest than usual, we can follow } \\
\text { the time and interest of students } \\
\text { nowadays }\end{array}$ & $\begin{array}{l}\text { Female students responded that } \\
\text { the activities carried out when } \\
\text { applying flipped classroom } \\
\text { learning method could improve }\end{array}$ \\
\hline
\end{tabular}




\begin{tabular}{|l|l|l|}
\hline \multirow{5}{*}{ Enough } & $\begin{array}{l}\text { pembelajaran seperti ini lebih } \\
\text { menarik dari pembelajaran } \\
\text { biasanya, bisa menyesuaikan } \\
\text { waktu dan ketertarikan siswa } \\
\text { sekarang }\end{array}$ & $\begin{array}{l}\text { their autonomy in learning } \\
\text { English. }\end{array}$ \\
\hline No & $\begin{array}{l}\text { Jadi terbiasa melaksanakan } \\
\text { pembelajaran out-class }\end{array}$ & \\
\hline Habits and Study Practices in & $\begin{array}{l}\text { Write the learning material at } \\
\text { home } \\
\text { menulis materi pembelajaran di } \\
\text { rumah }\end{array}$ & $\begin{array}{l}\text { The habits and activities which } \\
\text { could improve their autonomy are } \\
\text { in line with activities in flipped } \\
\text { classroom. }\end{array}$ \\
$\begin{array}{l}\text { looking for learning material in } \\
\text { others media } \\
\text { mencari materi pembelajaran dari } \\
\text { media lain }\end{array}$ & $\begin{array}{l}\text { - } \\
\text { checking and preview the material } \\
\text { before discussion in the class } \\
\text { memeriksa pembelajaran sebelum } \\
\text { besok dibahas dikelas } \\
\text { read the material, translate it, } \\
\text { matching video or movie } \\
\text { translate, nonton video terus bisa } \\
\text { juga nonton film }\end{array}$ & \\
\hline
\end{tabular}

Based on the table 4, for the first question the writers was found that female students ae in beginning level of autonomy. Based on the table, the students are able recognizing one's own needs and limitation, managing own's learning and have learning process. Abdelrazeq (2018) explained that those activities indicate some of autonomy manner. The second question, female students responded that the activities carried out when applying flipped classroom learning method could improve their autonomy in learning English. The last, there are several habits and activities which could improve their autonomy is in line with activities in flipped classroom.

Table 5. Interview Data Analysis - Male

\begin{tabular}{|l|l|l|}
\hline \multicolumn{2}{|c|}{ Interview Data Analysis } \\
\hline Group of Code & \multicolumn{1}{|c|}{ Code } & \multicolumn{1}{c|}{ Description } \\
\hline Level of Autonomy: & - & \multicolumn{1}{|c|}{} \\
$\begin{array}{l}\text { Advanced } \\
\text { Beginning }\end{array}$ & $\begin{array}{l}\text { Recognizing one's own needs and } \\
\text { limitation. }\end{array}$ & $\begin{array}{l}\text { Based on the codes, even male } \\
\text { students have autonmy activities } \\
\text { and characteristics, they still can } \\
\text { not optimize those activities. } \\
\text { Then, the researchers can be } \\
\text { concluded that male students are } \\
\text { in beginning level of autonomy. }\end{array}$ \\
& $\begin{array}{l}\text { Learner reflects learning process, } \\
\text { and thinks about oneself as a } \\
\text { learner. }\end{array}$ & \\
\hline
\end{tabular}




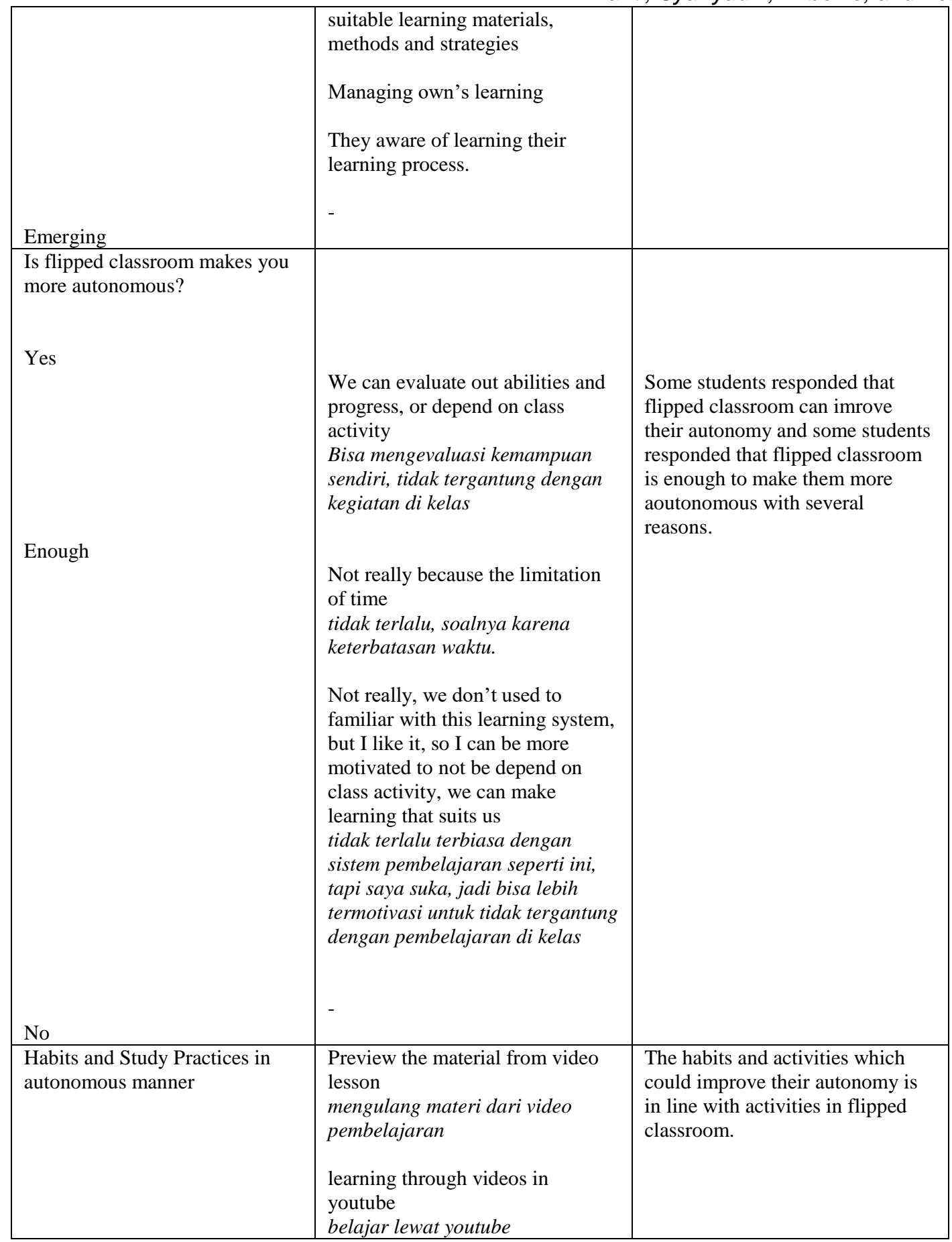

Based on the table 5, for the first question the writers was found that male students are in beginning level of autonomy. There is statement which indicates the characteristic of autonomy. The second question, some students responded that flipped classroom can improve their autonomy and some students responded that flipped classroom is enough to make them more autonomous with several reasons. The last, there are several habits and activities which could improve their autonomy is in line with activities in flipped classroom. 


\section{Discussion}

In this section, the result of the data will be elaborated. The present study described gender based students" learning aautonomy in English flipped cclassroom. The data were obtained from quantitative and qualitative research. There are two research questions which answered by three data collections. The first research question was answered by Learning Autonomy Questionnaire (LAQ) and pretest-posttest. The second research question was answered by interview. In the discussion of the result, te researchers was found similar findings with the previous study.

The first result of the study for answering the first research question: "Is there any significant difference between male and female students' learning autonomy by using flipped classroom and those who are not?" The researchers got the data from Learning Autonomy Questionnaire and pretest-posttest. Based on questionnaire, the researchers was found gender respons which discussed in the following tables :

Table 6. Gender Response of LAQ in Experimental Class

\begin{tabular}{|c|c|c|c|c|c|}
\hline \multirow{2}{*}{ Gender } & \multirow{2}{*}{$\mathrm{N}$} & \multicolumn{2}{|c|}{ Mean } & \multicolumn{2}{c|}{ Std. Deviation } \\
\cline { 3 - 6 } & & Pre LAQ & Post LAQ & Pre LAQ & Post LAQ \\
\hline Male & 11 & 25.18 & 46.90 & 1.991 & 8.665 \\
\hline Female & 19 & 29.74 & 51.47 & 4.736 & 3.322 \\
\hline
\end{tabular}

Table 7. Gender Response of LAQ in Control Class

\begin{tabular}{|c|c|c|c|c|c|}
\hline \multirow{2}{*}{ Gender } & \multirow{2}{*}{$\mathrm{N}$} & \multicolumn{2}{|c|}{ Mean } & \multicolumn{2}{c|}{ Std. Deviation } \\
\cline { 3 - 6 } & & Pre LAQ & Post LAQ & Pre LAQ & Post LAQ \\
\hline Male & 12 & 28.83 & 35.91 & 5.306 & 6.444 \\
\hline Female & 18 & 33.44 & 42.44 & 4.260 & 3.760 \\
\hline
\end{tabular}

In the previous chapter was explained that female students were got higher achievment than male students as what Awan and Azeem (2017, p. 369) mentioned in their study revealed that girls performed better than boys in curricular and co-curricular activities. In this present study the researchers was found similar findings in the concept of autonomy that female perfomed better in their autonomy than male. Based on the table 6 and 7 , it could be seen female indicates more autonomy than female in both of class even before the treatment or after the treatment.

Then, the researchers revealed the descriptive statistic of questionnaire. Based on the result of questionnaire experimental class got more positively in their autonomy after the Linguists: Journal of Linguistics and Language Teaching Vol. 7, No. 1, July 2021 

treatment of flipped model than control class with the treatment by using discovery learning. The items number 12 and 14 in post LAQ experimental class is proven that after applying flipped classroom, the students respond positively. This result is support the findings the study by Santikarn and Wichadee (2018, pp. 103-135) which mentioned that the class which taught by flipped classroom was becoming an autonomous learner. After that, the reesearcher conducted independent sample t-test, the calculating results showed that there is a significant difference in students' learning autonomy between students who are taught by means of flipped classroom and those who are not. The result is similar with what was stated by scholars (Santikarn \& Wichadee, 2018; Wahaibi \& Hashim, 2018; Shehata, 2018; Guo, 2017) which mentioned that flipped classroom is effective to enhance students' learning autonomy.

The result of pretest-posttest is indicated although the score of autonomy is increased, it does not have significant impact on their narrative reading comprehension test. It can be concluded the test results are not support the results of the Learning Autonomy Questionnaire (LAQ).

The second result of the study for answering the first research question: "To what extend does the use flipped classroom in English class impact gender based students' learning autonomy?" The researchers got the data from interview. Based on data analysis, after the treatment both of female and male students indicate positive opinion that flipped classroom can enhance their autonomy. Male students asserted that flipped classroom can motivate their selves to be autonomous learner, even though male students assert that there is no huge differencece before and after the treatment, contrast with female students who assert that there is improvement in their autonomy after the treatment. This is in line with what was point out that students have good perceptions on the flipped classroom as well as increase autonomy perceptions, the flipped classroom allows for more independence in learning (Santikarn \& Wichadee, 2018).

Finally, after conducting thematic analysis, start from on initial codes of the data, calculating and generalize the codes into the themes (Clarke \& Braun, 2013). The researcher was found there are levels of autonomy which divided into four levels: advanced, intermediate, beginning and emerging (Abdelrazeq, 2018, p. 729). The data showed that he students students are able recognizing one's own needs and limitation, managing own's learning activity and have learning process. Abdelrazeq (2018) explained that those activities indicate some of characteristics of autonomous learner and the researcher was found that both female and male students are in beginning level of autonomy. 
The results of this study have difference with the previous studies. Some previous studies had analyzed this topic of the study; however the researchers tried to analyze with the different purposes in identifying the data than previous studies. The first, Wahaibi and Hashim (2018, pp. 88-105), they conducted a study which entitled "Learner's Autonomy in Undergraduate English Flipped Course". The study aimed at examined the use of flipped classroom in an English course in affected students' autonomy compared to traditional approaches. The result was found that the experimental group was more autonomous than the traditional one.

The second, the study was conducted by Santikarn and Wichadee (2018, pp. 103135), the study was entitled "Flipping the Classroom for English Language Learners: A Study of Learning Performance and Perceptions". The purpose of the study was to assess how a modified "flipped classroom" had an impact on students' learning performance and perceptions. The study revealed that the class which taught by flipped classroom was becoming an autonomous learner.

The third, the study was conducted by Shehata (2018, pp. 37-80) which entitled “Using Flipped Learning for Enhancing Faculty of Education English Majors' Reflective Teaching Skills and Learning Autonomy". The study aimed at investigating the use of flipping learning for enhancing Faculty of Education English Majors' Reflective Teaching Skills and Learning Autonomy. The result indicates the use flipped learning significantly enhanced English majors' reflective teaching skills and learning autonomy.

From those previous studies, it can be seen that the previous studies did not focus on applying flipped classroom in enhanching students' learning autonomy and there is no previous studies discussed gender based students' learning autonomy in English class. Thus, in the present study, the researchers analyzed and explored more focus about gender based students' learning autonomy in English flipped classroom.

In this study, from the results of learning autonomy questionnaire showed that the students percieved positively in their learning autonomy after apllying flipped classroom. Moreover the calculating result of $t$ test revealed there is a significant difference in students' learning autonomy between students who are taught by means of flipped classroom and those who are. The result of interview also indicated that the students both of female and male percieved positively in their autonomy after the treatment of flipped classroom. On the other hand, pretest-posttest is indicated although the score of autonomy is increased, it does not have significant impact on their narrative reading comprehension test. 
In addition, the results of this study supported the results of previous studies, both of them has a good and positive results about applying flipped classroom. It can be concluded that flipped classroom has given a good impact in students' learning autonomy.

\section{CONCLUSION}

Based on result, there is a significant difference in students' learning autonomy between students who are taught by means of flipped classroom and those who are not. In addition, the researcher also investigated sudents learning autonomy based on gender identity, whereas the result of questionnaire is showed female indicates more autonomy than male in both of class even before the treatment or after the treatment. Then, the researcher conducted an interview to answered the second research question. Based on data analysis, after the treatment the students were claiming the activities in in-class and out-class sessions had treated the students how to be more autonomous learners. Both female and male students indicate a positive opinion that flipped classroom can enhance their autonomy, even though the data showed that female is more autonomy than male. Male student responds that there is no huge differences in their learning autonomy before and after the treatment of flipped classroom.

In conclusion, flipped classroom has given a good impact in students' learning autonomy even for female or male students, although not give significant impact on their learning outcomes especially in narrative reading comprehension. On the other hand, applying flipped classroom has weaknesses such as the availability of internet connection and smartphone as learning tool. Besides that, flipped classroom is required more activity for students to be able to follow the instructions in flipped classroom. The researchers expects that it is necessary to conduct the study for further researcherss in other level of education to gain more specific result related to the reason of applying flipped classroom to increase students' learning autonomy.

\section{REFERENCES}

Anggitasari, M., Tarwana, W., Febriani, R. B., \& Syafryadin, S. (2020). Using wattpad to promote the students' responses to literary works: efl college students' perspectives and experiences of enjoying short stories. Jadila: Journal of Development and Innovation in Language and Literature Education, 1(2), 182-192.

Abdelrazeq, A. (2018). Autonomous Learning Levels of Students Majoring in EFL and the Role of their Teachers in Developing Autonomous Learning. 12(4), 724-738. 
Anderson, V. (2015). Language Learner Autonomy: Both Sides of the Coin A study of EFL teachers' and students' perceptions of autonomy in Spain [Linköping University]. http://urn.kb.se/resolve?urn=urn:nbn:se:liu:diva-122476

Awan, A. G., \& Azeem, M. S. (2017). Gender differences and its impact on students' performance: a socio-linguistic analysis. Global Journal of Management, Social Sciences and Humanities, 3(2), 352-372.

Azwandi, A., Harahap, A., \& Syafryadin, S. (2019). Penyuluhan dan pelatihan ICT-Enhanced Teaching-Learning sebagai model pengembangan profesional guru di kota Bengkulu. Jurnal Pengabdian Masyarakat Ilmu Terapan (JPMIT), 1(1)

Becirovic, S. (2017). The relationship between gender, motivation and achievement in Learning English as a Foreign Language. European Journal of Contemporary Education, 6(2), 210-220. https://doi.org/10.13187/ejced.2017.2.210

Begarmann, J., \& Sams, A. (2012). Flip your classroom: Reach every student in every class every day.

Benson, P., \& Voller, P. (1997). Autonomy and independence in language learning. In Autonomy and Independence in Language Learning. https://doi.org/10.4324/9781315842172

Bussey, K. (2011). Handbook of Identity Theory and Research. Handbook of Identity Theory and Research. https://doi.org/10.1007/978-1-4419-7988-9

Chan, J. Y. H. (2018). Gender and attitudes towards English varieties: Implications for teaching English as a global language. System, 76, 62-79. https://doi.org/10.1016/j.system.2018.04.010

Clarke, V., \& Braun, V. (2013). Teaching thematic analysis: Overcoming challenges and developing strategies for effective learning. 26, 120-123.

Creswell, J. W. (2014). RESEARCH DESIGN: Qualitative, Quantitative, and Mixed Methods Approaches (4th ed.). SAGE Publication, Inc.

Guo, M. S. (2017). Investigating the Effect of the Flipped Classroom Using E-Learning on Language Proficiency, Learner's Autonomy, and Class Participation of English Language Learners. International Conference on Advanced Learning Technologies, 346-350. https://doi.org/10.1109/ICALT.2017.60

Handayani, S., Youlia, L., Febriani, R.B., Syafryadin, S. (2020). The use of digital literature in teaching reading narrative text. Journal Of English Teaching, Applied Linguistics And Literatures (JETALL). 3(2), 65-74.

Irianti, L., \& Sulastri, F. (2018). Flipped Learning In Listening Class: Best Practice Approaches and Implementation. 2, 248-257.

Kostaris, C., Sergis, S., Sampson, D. G., Giannakos, M. N., \& Pelliccione, L. (2017). Investigating the potential of the flipped classroom model in K-12 ICT teaching and learning: An action research study. Educational Technology and Society, 20(1), 261273.

Little, D. (2007). Language Learner Autonomy: Some Fundamental Considerations Revisited. Innovation in Language Learning and Teaching, 1(1), 14-29. https://doi.org/10.2167/illt040.0

Loi, N. Van. (2017). Promoting learner autonomy: Lesson from using project work as a supplement in English skills courses. Can Tho University Journal of Science, 07, 118125. https://doi.org/10.22144/ctu.jen.2017.057

Linguists: Journal of Linguistics and Language Teaching

Vol. 7, No. 1, July 2021 
Martina, F., \& Afriani, Z.L. (2020). Pelatihan pendekatan Genre-Based pada pembelajaran skill menulis bagi guru bahasa Inggris SMPN 10 kota Bengkulu. Jurnal Inovasi Pengabdian Masyarakat Pendidikan, 1(1). 57-73.

Santikarn, B., \& Wichadee, S. (2018). Flipping the classroom for English language learners: A study of learning performance and perceptions. International Journal of Emerging Technologies in Learning, 13(9), 123-135. https://doi.org/10.3991/ijet.v13i09.7792

Shehata, M. G. M. (2018). Using Flipped Learning for Enhancing Faculty of Education English Majors' Reflective Teaching Skills and Learning Autonomy. Journal of Research in Curriculum, Instruction and Educational Technology, 4(4), 37-80.

Syafryadin, H., \& Salniwati, A. R. A. P. Digital Storytelling Implementation for Enhancing Students' Speaking Ability in Various Text Genres. International Journal of Recent Technology and Engineering (IJRTE). 8(4), 3147-3151

Syahrial, S., \& Syafryadin, S. (2020). Pelatihan menjadi guru bahasa Inggris kreatif dan milenial di sekolah menengah pertama bengkulu Tengah. Jurnal Inovasi Pengabdian Masyarakat Pendidikan. 1(1). 18-35.

Vantieghem, W., Vermeersch, H., \& Van Houtte, M. (2014). Transcending the gender dichotomy in educational gender gap research: The association between gender identity and academic self-efficacy. Contemporary Educational Psychology, 39(4), 369-378. https://doi.org/10.1016/j.cedpsych.2014.10.001

Wahaibi, S. S. Al, \& Hashim, S. (2018). Learner's Autonomy in an Undergraduate English Flipped Course. International Journal of Scientific Research and Innovative Technology, 5(8), 88-105. www.ijsrit.com

Zhang, L. X., \& Li, X. X. (2004). A comparative study on learner autonomy between Chinese students and west European students. Foreign Language World, 4, 15-23. 